\title{
Effect of donor islet mass on metabolic normalization in streptozotocin-diabetic rats
}

\author{
B. Keymeulen ${ }^{1}$, H.Teng ${ }^{1}$, M. Vetri ${ }^{1}$, F. Gorus ${ }^{1}$, P. In’t Veld ${ }^{2}$ and D. G. Pipeleers ${ }^{1}$ \\ ${ }^{1}$ Department of Metabolism and Endocrinology, ${ }^{2}$ Department of Pathology, Vrije Universiteit Brussel, Brussels, Belgium
}

\begin{abstract}
Summary. The effect of donor islet mass on the metabolic normalization in streptozotocin-diabetic rats was examined by comparing normal control rats with two transplant groups receiving 800 or 2,000 islets intraportally, i. e. grafts containing respectively, 0.8 or 2 million Beta cells at $70 \%$ purity. After transplantation, basal glycaemia and daily urine volumes normalized in all recipients and remained normal in both groups over the 20 -week follow-up period. After intragastric glucose challenge, the 800 -islet group exceeded the normal range of glycaemia at all tested time points $(0-$ $120 \mathrm{~min}$ ) whereas the 2,000-islet group exhibited higher glycaemia only at 15 and $30 \mathrm{~min}$; no deterioration in glucose tolerance occurred during the 20-week follow-up. Both transplant groups presented lower serum fructosamine levels than diabetic control rats, normal levels being maintained only in the 2000-islet group. At post-transplantation week 21,
\end{abstract}

both recipient groups exhibited the same body weight as age matched normal control rats, but their serum triglyceride levels were significantly higher. Hepatic insulin contents were comparable to the insulin contents of the grafts at the time of implantation, representing 16 or $40 \%$ of the pancreatic insulin content in the age-matched control rats. Although islet grafts with 0.8 million Beta cells can restore basal glycaemia in adult streptozotocin-diabetic rats, implants of 2 million Beta cells are necessary to correct other parameters of glucose homeostasis. The present data indicate the need of determining the number of grafted Beta cells in studies on the metabolic outcome of islet cell transplantation. DNA content and percentage of Beta cells in the graft are proposed as useful parameters.

Key words: Islet transplantation, diabetes mellitus.
The aim of islet transplantation is to prevent the chronic complications which can develop as a result of chronic hyperglycaemia. Implantation of islets has been shown to correct basal glycaemia in diabetic rodents, dogs, monkeys and humans [1-4]. However, this effect may diminish over time, as a return to a diabetic state has been noticed during follow-up periods of 24 months and longer [5-8]. Furthermore, it is still uncertain whether normal glucose tolerance can be established and maintained in islet recipients $[9,10]$. The present study compares glucose control in streptozotocin-diabetic recipient and age-matched normal control rats over a 20 -week period. In order to examine the effect of islet mass on the metabolic normalization, two groups of recipients were included, one receiving 2.5 fold more islet tissue than the other. As islet counts are not a reliable parameter of Beta-cell mass in our laboratory, we derived the number of Beta cells in the islet grafts from their DNA content and their percentage of Beta cells. It was thus calculated that the recipients received, respectively, 0.8 million and 2 million Beta cells at a $70 \%$ purity.

\section{Materials and methods}

\section{Animals}

Inbred adult male Lewis rats (age 8-10 weeks) were used as donors and recipients (Charles River, Sulzfeld, FRG). Recipients were rendered diabetic by intravenous injection of $60 \mathrm{mg} / \mathrm{kg}$ streptozotocin (Sigma, St. Louis, Mo., USA, freshly dissolved in citrate buffer $(\mathrm{pH}$ 4.5)). One week after injection, the diabetic state was confirmed by glycaemia ( 2 -h fast) above $22 \mathrm{mmol} / \mathrm{l}$, daily urine volumes above $100 \mathrm{ml}$ and weight loss. Donor islets were prepared according to a modified collagenase method [11].

\section{Graft preparation and transplantation}

Isolated islets were distributed in groups of 1000 per bacteriologic petri-dish $(9 \mathrm{~cm}$ diameter; Nunc, Roskilde, Denmark) and suspended in $9 \mathrm{mI} \mathrm{HAM} \mathrm{F10} \mathrm{(Flow} \mathrm{Laboratories,} \mathrm{Irvine,} \mathrm{UK)} \mathrm{contain-}$ ing $10 \mathrm{mmol} / \mathrm{l}$ glucose, supplemented with $25 \mu \mathrm{mol} / 1$ isobutylmethylxantine (Janssen, Beerse, Belgium), $2 \mathrm{mmol} / \mathrm{l} \mathrm{L}$-glutamine, $1 \%$ bovine serum albumin (Sigma), $0.075 \mathrm{mg} / \mathrm{ml}$ benzathine penicillin and $0.1 \mathrm{mg} / \mathrm{ml}$ streptomycin sulphate. After $24 \mathrm{~h}$ of culture at $37^{\circ} \mathrm{C}$ the islets were collected, centrifuged through percoll (density $1.04 \mathrm{~g} / \mathrm{ml}$; Pharmacia, Uppsala, Sweden) and counted under a dis- 
Table 1. Composition of islet grafts

\begin{tabular}{rlcl}
\hline Graft & $\begin{array}{l}\text { Insulin } \\
(\mu \mathrm{g} / \text { implant })\end{array}$ & $\begin{array}{l}\text { DNA } \\
(\mu \mathrm{g} / \text { implant })\end{array}$ & $\begin{array}{l}\text { Insulin/DNA } \\
(\mu \mathrm{g} / \mu \mathrm{g})\end{array}$ \\
\hline 800 islets & $19.1 \pm 4.2$ & $8.7 \pm 3.3$ & 2.4 \\
2000 islets & $59.2 \pm 19.0$ & $22.0 \pm 4.0$ & 2.7 \\
\hline
\end{tabular}

Values represent mean \pm SD of six experiments

secting microscope. Grafts consisting of 800 or 2,000 islets were prepared after samples were taken for hormone and DNA assays, for electron microscopical analysis of cell composition and for light microscopical determination of the percentage of insulin-positive cells [11]. Grafts were suspended in $400 \mu \mathrm{l}$ of albumin-free medium, supplemented with $10 \%$ rat serum, and injected in the portal vein of diabetic animals, 2 weeks after streptozotocin administration [12]. All recipients survived throughout the 21 -week post-transplant study period. Normal control rats were sham transplanted.

\section{Metabolic follow-up}

Islet recipients were followed in metabolic cages allowing measurement of 24-h urine volumes. At post-transplantation weeks 4, 12 and 20 , blood samples were taken from a tail incision in non-anaesthetized animals, after a 2 -h fast in the morning (basal). Basal blood glucose levels (measured by glucose oxidase, Glucopath and Glucoscot II, Kindly donated by Menarini Diagnostics, Benelux, Brussels, Belgium) under $7.2 \mathrm{mmol} / 1$ (mean control $+2 \mathrm{SD}$ ) were considered as normalized. Glucose tolerance was only assessed in rats with normalized basal glycaemia. The test involved intragastric administration of a $30 \%$ glucose solution $(2 \mathrm{~g} / \mathrm{kg})$ as a single bolus in non-anaesthetized animals. Glycaemia was measured 15, 30, 60, 90 and 120 min later. At post-transplantation weeks 8, 16 and 21, tail blood was collected for measuring serum fructosamine levels [13] as an index of the degree of protein glycation. Since $24-\mathrm{h}$ urine volumes could not be collected without contamination by food or faeces, serum creatinine levels were measured [14] instead of microalbuminuria as an index of kidney function. Serum lipid levels were determined by triglyceride [15] and cholesterol [16] measurements. Animals were decapitated at week 21 and their liver and pancreas extracted for insulin assay [17].

\section{Statistical analysis}

All data are expressed as mean \pm SD of $n$ experiments. Statistical significance of the difference between experimental groups was calculated by Macintosh Statview $512^{+}$one-way analysis of variance.

\section{Results}

\section{Characteristics of grafts}

The grafts were examined at the time of transplantation, $24 \mathrm{~h}$ after the islet isolation procedure. Electron microscopy indicated signs of cell damage in 4 to $16 \%$ of the cells. The ultrastructurally intact cells were identified as endocrine (78-88\% of total), non-granulated (4 to $10 \%$ ) or exocrine (less than $5 \%$ ). Immunostaining for insulin was positive for $70 \%$ of the total cell population. Considering the DNA content of rat islet cells $\left(7.3 \mu \mathrm{g} / 10^{6}\right.$ cells, [18]), the DNA content of the grafts (Table 1) appears the equivalent of 1.2 or 3.0 million cells in, respectively, the 800 or 2000 islet grafts. In view of the percentage of insulin-positive cells, the implants should contain approximately 0.8 or 2 million Beta cells. The measurements of DNA and insulin contents confirm that the size of the 2,000 islet graft was 2.5-fold larger than that of the 800 islet graft.

\section{Effect on overt symptoms of diabetes}

Transplantation of 800 and 2,000 islets corrected daily urine volumes and basal glucose levels in all recipients (Table 2). Normalization of diuresis occurred faster in the 2,000-islet recipients (median 2 days, range 2-16 days) than in the 800-islet recipients (median 9 days, range 879 days). No statistically significant differences were found between the respective urine volumes and basal glycaemia of both transplant groups (Table 2). Within each group, these values did not deteriorate over the 20week follow-up period (Tables 2 and 3). Comparison with the normal control group indicated that the 800-islet transplanted animals exhibited a slightly higher basal glucose level at week 20 , but not at earlier time points (Table 2). This difference seemed to be caused by a slight time-related decrease in basal glycaemia of normal control rats instead of an increase of the levels in these transplants (Table 2). No difference was measured between the glycaemia of 2,000-islet recipients and normal controls (Table 2).

\section{Effect on glucose tolerance}

An intragastric glucose tolerance test was performed in animals with basal glycaemia less than $7.2 \mathrm{mmol} / 1$ on the day of testing. In each transplant group, one animal had to be excluded for one test on the basis of a glycaemia above $7.2 \mathrm{mmol} / \mathrm{l}$ (Table 3). Compared to normal control rats, recipients of 800 islets exhibited significantly higher glucose levels at all time points (15 to $120 \mathrm{~min}$ post-loading) whether they were tested 4,12 or 20 weeks following transplantation (Fig.1). This glucose intolerance did not

Table 2. Basal glycaemia (G) and daily urine volume (U) after implantation of 800 or 2000 islets

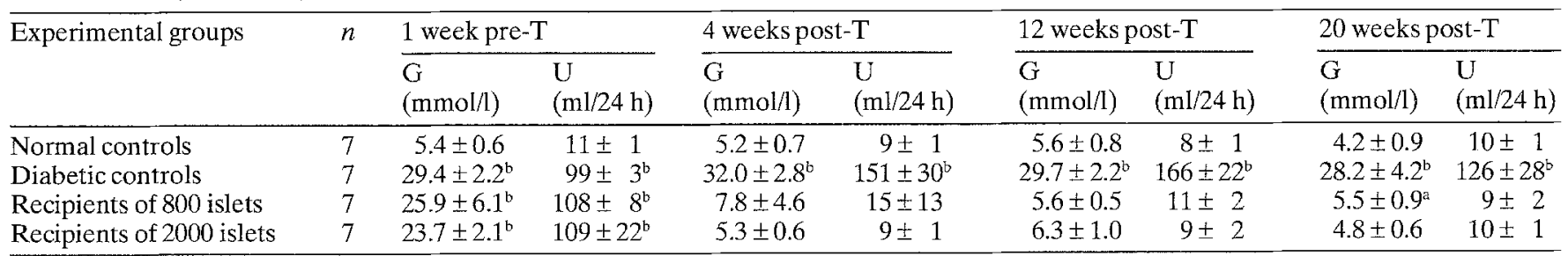

${ }^{\mathrm{a}} p<0.05,{ }^{\mathrm{b}} p<0.005$ vs normal control group. All values are expressed as mean $\pm \mathrm{SD}$ in $n$ animals, tested pre- and post-transplantation (pre T/post-T) 
Table 3. Effect of graft size on glucose control in islet transplants

\begin{tabular}{|c|c|c|c|c|c|c|c|}
\hline \multirow[t]{2}{*}{ Graft } & \multirow[t]{2}{*}{ Parameter } & \multicolumn{6}{|c|}{ Number of recipients at post-transplant week } \\
\hline & & 4 & 8 & 12 & 16 & 20 & 21 \\
\hline 800 islets & $\begin{array}{l}\text { Glycaemia }<7.2 \mathrm{mmol} / \mathrm{l} \\
\text { - Basal } \\
\text { - GTT } 120 \mathrm{~min} \\
\text { Fructosamine }<170 \mu \mathrm{mol} / \mathrm{l}\end{array}$ & $\begin{array}{l}6 \\
1\end{array}$ & 7 & $\begin{array}{l}7 \\
5\end{array}$ & 7 & $\begin{array}{l}7 \\
5\end{array}$ & 0 \\
\hline 2000 islets & $\begin{array}{l}\text { Glycaemia }<7.2 \mathrm{mmol} / \mathrm{l} \\
\text { - Basal } \\
\text { - GTT } 120 \mathrm{~min} \\
\text { Fructosamine }<170 \mu \mathrm{mol} / \mathrm{l}\end{array}$ & $\begin{array}{l}7 \\
6\end{array}$ & 7 & $\begin{array}{l}6 \\
6\end{array}$ & 7 & $\begin{array}{l}7 \\
7\end{array}$ & 6 \\
\hline
\end{tabular}

In each group of seven recipients, the number of animals is listed with glycaemia $<7.2 \mathrm{mmol} / \mathrm{l}$ (mean normal control $+2 \mathrm{SD}$ ), fructosamine $<170 \mu \mathrm{mol} / \mathrm{h}$ (mean normal control $+2 \mathrm{SD}$ ) and normal

deteriorate with time over the 20-week follow-up period. In fact, the number of animals with normal glycaemia at $120 \mathrm{~min}$ (i.e. $<7.2 \mathrm{mmol} / \mathrm{l}$ ) was higher at week 20 than at week 4 (Table 3 ). When the 2,000-islet recipients were compared to the normal controls, their 15-30 min glycaemia was higher; on the other hand their 60-90 and 120 min glycaemia was not statistically different for any of the tests (Fig. 1). As in the 800-islet group, no deterioration in glucose tolerance was observed over the 20 -week follow-up period. Comparison of the two transplant groups indicated that the 800 -islet recipients exhibited statistically higher values at all time points following a glucose load at post-transplantation week 4 (Fig. 1); at week 12 and 20 , a difference was only noted at one or two time points (Fig. 1).

\section{Effect on serum fructosamine}

Untreated diabetic control rats presented almost threefold higher serum fructosamine levels than sham-treated normal controls $(p<0.005)$ (Table 4$)$. This increase was prevented by islet transplantation. Recipients of 2,000 islets had normal levels at post-transplant weeks 8,16 and 21 . Six of the seven animals in this group maintained normal fructosamine levels throughout the 21 week followup period. This contrasts with the 800 -islet recipient group where fructosamine levels remained significantly higher than normal control values up to 21 weeks post-transplantation (Table 4). Fructosamine levels in the 800 -islet recipient group were significantly lower than in diabetic control rats $(p<0.005)$, but higher than in the 2000-islet recipient group $(p<0.05)$. With time, an increase in fructosamine levels occurred in the 800-islet recipient group, but not in the 2000-islet recipient group (Table 4).

\section{Effect on other metabolic parameters}

On the day of transplantation, mean body weight of diabetic control rats $(226 \pm 24 \mathrm{~g})$ was not different from that in islet recipients (800-islet group $236 \pm 25 \mathrm{~g}, 2,000$ islet group $254 \pm 10 \mathrm{~g}$ ) but $30 \%$ lower than that in the normal control group ( $323 \pm 8 \mathrm{~g} ; p<0.005)$. Twenty weeks after transplantation, body weight in the normal control group had increased by $37 \%(443 \pm 14 \mathrm{~g})$ while it glycaemia (mean normal control +2 SD) 120 min after intragastric glucose tolerance test (GTT-120 min)

remained unchanged in untreated diabetic animals $(200 \pm 24 \mathrm{~g})$. Transplantation resulted, within 20 weeks, in a $90 \%$ weight gain in both groups ( 800 islets $463 \pm 70 \mathrm{~g}$, 2000 islets $476 \pm 49 \mathrm{~g}$ ) reaching the range of the agematched normal control rats.

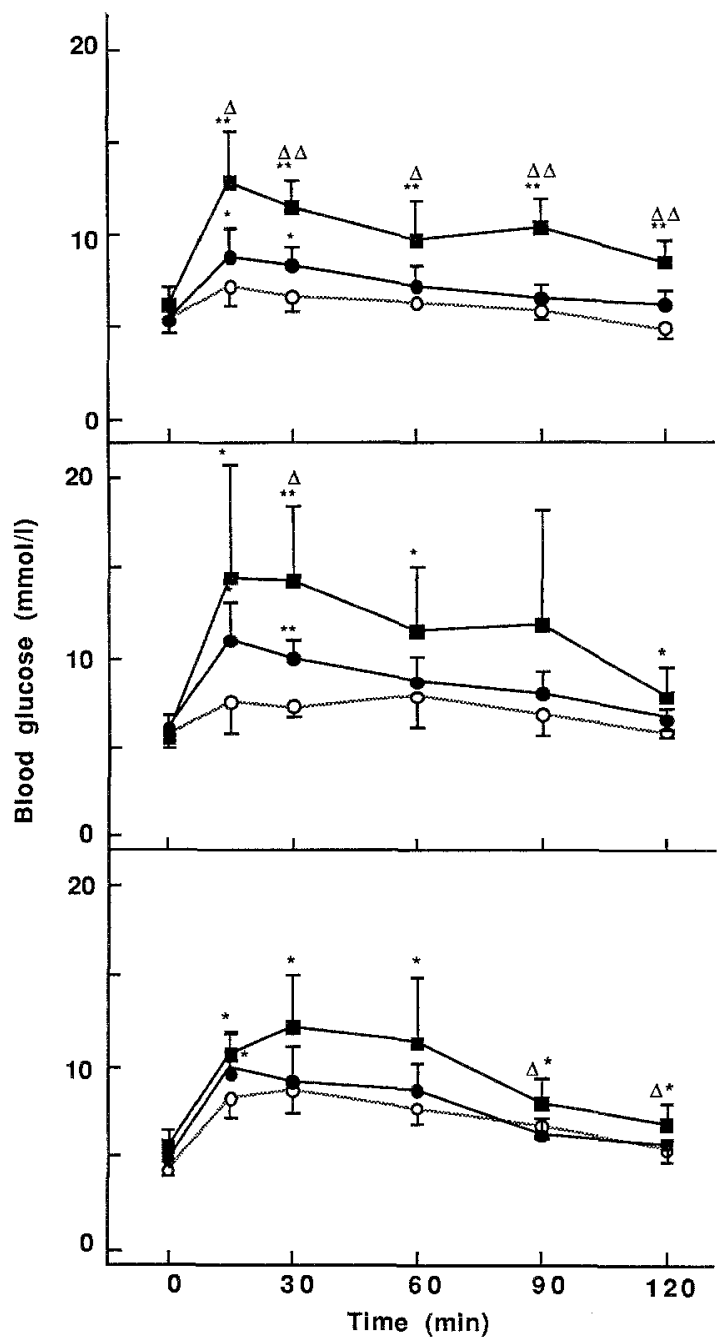

Fig. 1. Intragastric glucose tolerance test at 4 (upper panel), 12 (middle panel) and 20 (lower panel) weeks after implantation in normal control animals $(0--)$ ), and recipients of $800(\mathbf{E}-\mathbf{m})$ or 2000 $(\bullet)$ islets. All values are expressed as mean \pm SD in seven animals. Statistical difference is determined vs controls $\left(^{*} p<0.05\right.$, $\left.*_{*} * p<0.005\right)$ and among recipient groups $(\Delta p<0.05, \Delta \Delta p<0.005)$ 
Table 4. Serum fructosamine levels $(\mu \mathrm{mol} / \mathrm{l})$ after implantation of islet grafts with varying size

\begin{tabular}{lllll}
\hline Experimental groups & $n$ & 8 weeks post-T & 16 weeks post-T & 21 weeks post-T \\
\hline Normal controls & 7 & $126 \pm 11$ & $142 \pm 14$ & $127 \pm 15$ \\
Diabetic controls & 7 & $323 \pm 48$ & $302 \pm 45^{\mathrm{c}}$ & $369 \pm 63^{\mathrm{c}}$ \\
Recipients of 800 islets & 7 & $153 \pm 9$ & $163 \pm 7$ & $201 \pm 19^{\mathrm{acd}}$ \\
Recipients of 2000 islets & 7 & $131 \pm 23$ & $148 \pm 12$ & $153 \pm 24^{\mathrm{b}}$ \\
\hline
\end{tabular}

All values are expressed as mean $\pm \mathrm{SD}$ in $n$ animals, tested at different episodes post-transplantation (post-T). All diabetic control values are significantly $(p<0.005)$ higher than normal control values and those in both transplant groups. Recipient values are compared with normal control animals ( $\left.{ }^{\mathrm{a}} p<0.005\right)$. Statistical significance is also determined for differences among both recipient groups $\left({ }^{b} p<0.05\right)$. The time-dependent change in values within one experimental group is examined by determining statistical significance of differences with the values measured at 8 week $\left({ }^{c} p<0.005\right)$ and 16 week post-transplantation ( $\left.{ }^{\mathrm{d}} p<0.005\right)$

Table 5. Serum lipid and creatinine levels in islet transplant recipients

\begin{tabular}{lllll}
\hline Experimental groups & $n$ & $\begin{array}{l}\text { Cholesterol } \\
(\mathrm{mmol} / \mathrm{l})\end{array}$ & $\begin{array}{l}\text { Triglycerides } \\
(\mathrm{mmol} / \mathrm{l})\end{array}$ & $\begin{array}{l}\text { Creatinine } \\
(\mu \mathrm{mol} / \mathrm{l})\end{array}$ \\
\hline Normal controls & 7 & $2.31 \pm 0.18$ & $0.94 \pm 0.22^{\mathrm{b}}$ & $49.5 \pm 12.4^{\mathrm{b}}$ \\
Diabetic controls & 7 & $2.57 \pm 0.31$ & $3.01 \pm 0.93^{\mathrm{a}}$ & $75.1 \pm 10.6^{\mathrm{a}}$ \\
Recipients of 800 islets & 7 & $2.70 \pm 0.44$ & $1.75 \pm 0.56^{\mathrm{ab}}$ & $56.6 \pm 9.7^{\mathrm{b}}$ \\
Recipients of 2000 islets & 7 & $2.55 \pm 0.18$ & $1.89 \pm 0.92^{\mathrm{ab}}$ & $58.3 \pm 8.3^{\mathrm{b}}$ \\
\hline
\end{tabular}

${ }^{\mathrm{a}} p<0.05 \mathrm{vs}$ normal control group; ${ }^{\mathrm{b}} p<0.05$ vs diabetic control group. All values are expressed as mean $\pm \mathrm{SD}$ of $n$ animals tested at post-transplant week 21

Table 6. Insulin stores in islet recipients 21 weeks after implantation

\begin{tabular}{lllr}
\hline Experimental groups & $n$ & $\begin{array}{l}\text { Liver } \\
(\mu \mathrm{g} / \text { organ })\end{array}$ & $\begin{array}{l}\text { Pancreas } \\
(\mu \mathrm{g} / \text { organ })\end{array}$ \\
\hline Normal controls & 6 & $<0.1$ & $143.1 \pm 19.3$ \\
Diabetic controls & 5 & $<0.1$ & $0.9 \pm 0.4$ \\
Recipients of 800 islets & 5 & $23.3 \pm 4.6$ & $5.8 \pm 3.9$ \\
Recipients of 2000 islets & 6 & $60.9 \pm 17.4^{\mathrm{a}}$ & $3.5 \pm 1.3$ \\
\hline
\end{tabular}

All values are expressed as mean $\pm \mathrm{SD}$ in $n$ animals. Recipient groups consisted of animals with a normal glycaemia 120 min after intragastric glucose challenge $(2 \mathrm{~g} / \mathrm{kg}$ ) at week 20 (see Table 2 ). The liver values in recipient groups were statistically higher than in normal and diabetic control groups $(p<0.005)$; hepatic insulin content in 2000-islet recipients was significantly higher than that in 800 -islet recipients $\left({ }^{a} p<0.005\right)$. The pancreas values in the diabetic control group and in recipients were statistically lower than in the normal control groups $(p<0.005)$; the pancreas values in recipients were statistically higher than in the diabetic control group $(p<0.05)$

At post-transplantation week 21, serum triglyceride levels in islet recipients were lower than in diabetic controls $(p<0.05)$ but two-fold higher than in normal controls $(p<0.05)$ (Table 5). Cholesterol levels were comparable in all experimental groups. Serum creatinine in transplanted animals was lower than in untreated diabetic rats $(p<0.05)$ and comparable to the normal control values (Table 5).

\section{Insulin stores in islet recipients}

Before implantation, islet grafts contained approximately $20 \mu \mathrm{g}$ (800 islets) and $60 \mu \mathrm{g}$ (2000 islets) insulin. Similar amounts of insulin were recovered in the liver of longterm (i.e. 21 week) transplanted animals which had a normal 120 min glycaemia during an intragastric tolerance test at week 20 (Table 6). This insulin content of the liver corresponded to, respectively, 16 and $43 \%$ of the pancreatic insulin content in age-matched normal control ani- mals (Table 6). The pancreatic insulin content in diabetic controls was less than $1 \%$ of that in normal control animals. The presence of a hepatic insulin store was associated with a slightly higher pancreatic insulin store, but the size of the latter remained negligable; it was not higher in the 2,000-islet recipients than in the 800 -islet recipients (Table 6).

\section{Discussion}

The present study compares the degree of metabolic normalization in streptozotocin-diabetic recipients of isolated islets containing either 0.8 million or 2 million Beta cells at a $70 \%$ purity. Classically used parameters such as basal glycaemia and daily urine volume normalized in both recipient groups, but a longer delay was noted before normalization in recipients of the smaller grafts. The values were comparable in both transplant groups and remained constant over the 20 -week follow-up period. However, at post-transplant week 20, basal glycaemia of 800 -islet transplants was slightly higher than that in normal control rats; although this was not the case in the 2,000-islet recipients.

After intragastric glucose challenge, islet transplanted animals exhibited higher blood glucose levels than normal control rats. In the 800-islet group, glycaemia was higher at all time points, whereas this was only the case for the 15 and 30-min values in the 2,000-islet group. These results indicate that the lower donor mass is less efficient in controlling a glucose challenge. Implantation of a larger mass (2000 islets) established normal tolerance curves between 30 and $120 \mathrm{~min}$ but did not prevent the occurrence of higher glucose levels during the first $30 \mathrm{~min}$ of the test. It is conceivable that a further increase in islet mass could correct the glucose level during this first phase of the challenge. On the other hand, the glucose responsiveness of the Beta-cell implant may also occur along a different 
dose-response curve than that of pancreatic Beta cells, possibly as a result of a different biosociology of the grafted Beta cells [19]. Differences in microanatomy [20], in vascularization $[21]$ and in innervation $[9,10]$ may possibly induce such functional differences. During a 20-week follow-up period, glucose tolerance in islet transplanted animals did not deteriorate; at all episodes of testing, glucose control in the 30-120 min period was better in the 2,000-islet group than in the 800-islet group.

Thus, intraportal islet transplantation can induce an almost normal state of glucose tolerance following intragastric challenge, provided that a sufficient number of Beta cells are grafted. The present data suggest that more than 0.8 million Beta cells should be implanted to reach this goal in adult rats. Previous failures to normalize basal and challenged glucose levels may be caused by an insufficient size of the initial graft $[5,6,9,10]$. In contrast to other reports $[5,6]$, we have not detected a deterioration in glucose control in long-term transplanted animals. However, our study was conducted over a period of 20 weeks, whereas others have followed islet transplants for over 50 weeks $[5,6]$. The design of our study consisted of first determining the size of the islet mass which would be metabolically sufficient during a 20 -week period, before performing the experiment over a longer time period.

Normal fructosamine levels were maintained in the 2,000 -islet group but not in the 800 -islet group where the values were significantly elevated at post-transplantation week 21. Body weight of both islet transplant groups increased similarly to that of normal controls, indicating that the insulin release from the grafts was sufficient to fill body lipid reserves to the same extent as in normal controls. Serum triglyceride levels were not completely normalized by an 800 -islet graft, confirming a previous observation [22]. Implantation of a larger islet mass did not further correct this metabolic abnormality, raising the possibility of a reduced clearance of circulatory lipoproteins or of their increased production, for example in liver tissue that is chronically exposed to high insulin levels in the vicinity of the islet implants. Hepatocytes which surround the implanted islets present heavy steatosis [12] and may thus be responsible for an increased release of triglyceride-rich very low density lipoproteins. Long-term studies are needed to assess possible consequences on the degree of atherogenesis.

Twenty-one weeks after transplantation, insulin reserves in the liver were comparable in size to those in the initial grafts. Since it is unknown whether the Beta cells in the liver exhibited the same degree of granulation as before their implantation, we cannot conclude that the number of donor Beta cells has been preserved. Comparison of the hepatic insulin contents in both recipient groups indicated a similar ratio as in the initial grafts. Implantation of 2.5 times more islet tissue did not result in a proportionally higher or lower recovery of insulin from the host organs 20 weeks later. The recipients of the larger islet mass exhibited hepatic insulin reserves which were twofold lower than the pancreatic insulin stores in agematched normal control rats. They nevertheless maintained a fairly normal glucose homeostasis during the 21 week follow-up period. This normalization was associated with a small, but significant increase in pancreatic insulin content, possibly as a result of regranulation in Beta cells which survived the exposure to streptozotocin. The size of the pancreatic insulin reserve in islet transplants is, however, negligible compared to that in the liver; it does not appear to be influenced by the size of the hepatic insulin reserve.

It is concluded that the degree of long-term metabolic normalization in diabetic recipients of islet grafts varies with the number of Beta cells in the implant. Whereas grafts with 0.8 million Beta cells correct basal glycaemia in adult streptozotocin-diabetic rats, implantation of 2 million Beta cells was necessary to correct other parameters of glucose homeostasis such as intragastric tolerance tests and circulating fructosamine levels. Insulin reserves in 20week-transplanted rats were comparable to the insulin content of the islet grafts at the time of implantation, which contrasts with the poor recovery of insulin after transplantation of pancreatic fragments in dogs $(15 \%$, [23]). However, when compared to the pancreatic insulin content in age-matched normal control rats, insulin reserves in rats receiving the larger islet mass represented only $40 \%$. Further experiments are needed to examine whether this reduced hormonal reserve has any long-term functional consequences. In view of the present data, assessments of the metabolic outcome of islet cell transplantation require information on the number of implanted Beta cells and on the degree of contamination by other cell types. We propose determination of DNA content and Beta cell percentage in each islet graft. Both parameters can be measured prior to implantation if the grafts are prepare from cultured tissue. Passage through culture offers the additional advantage of enriching the tissue in endocrine cells and of reducing its immunogenicity.

Acknowledgments. The authors thank Mr. B. Vanbrabant, Ms C.De Crick, Ms M.Berghmans and Mr. G. Schoonjans for their technical assistance and Ms N. Van Slycke for her secretarial work. This work was supported by grants from the Belgian Ministerie Wetenschapsbeleid (Geconcenteerde Aktie 86/91-102) and from the Belgian Fonds voor Geneeskundig Wetenschappelijk Onderzoek (3.0075.88). It was undertaken within the framework of a European concerted action on "The treatment of diabetes by islet cell transplantation". Mr. B. Keymeulen is a Research Assistant at the Belgian National Fund for Scientific Research.

\section{References}

1. Kemp CB, Knight MJ, Scharp DW, Lacy PE, Ballinger WF (1973) Transplantation of isolated pancreatic islets into the portal vein of diabetic rats. Nature 244: 447 (Letter)

2. Warnock GL, Rajotte RV (1988) Critical mass of purified islets that induce normoglycemia after implantation into dogs. Diabetes 37: 467-470

3. Sutton R, Gray DW, McShane P, Peters M, Morris PJ (1987) The metabolic efficiency and long-term fate of intra-portal islet grafts in the cynomolgus monkey. Transplant Proc 19: 3575-3576

4. Warnock GL, Kneteman NM, Ryan E, Seelis REA, Rabinovitch A, Rajotte RV (1991) Normoglycaemia after transplantation of freshly isolated and cryopreserved pancreatic islets in type 1 (insulin-dependent) diabetes mellitus. Diabetologia 34: 55-58

5. Orloff MJ, Macedo A, Greenleaf GE, Girard B (1988) Comparison of the metabolic control of diabetes achieved by whole pan- 
creas transplantation and pancreatic islet transplantation in rats. Transplantation 45: 307-312

6. Hiller WF, Klempnauer J, Luck R, Steiniger B (1991) Progressive deterioration of endocrine function after intraportal but not kidney subcapsular rat islet transplantation. Diabetes 40 : $134-140$

7. Alejandro R, Cutfield RG, Shienvold FL et al. (1986) Natural history of intrahepatic canine islet cell autografts. J Clin Invest 78: $1339-1348$

8. Kaufman DB, MorelP,Field MJ, Munn SR, Sutherland DE(1990) Purified canine islet autografts. Transplantation 50:385-391

9. Pipeleers DG, Pipeleers-Marichal MA, Karl IE, Kipnis DM (1978) Secretory capability of islets transplanted intraportally in the diabetic rat. Diabetes $27: 817-824$

10. Trimble ER, Siegel ER, Berthoud HR, Renold AE (1980) Intraportal islet transplantation: functional assessment in conscious unrestrained rats. Endocrinology 106: 791-797

11. Pipeleers DG, Pipeleers-Marichal M, Hannaert JC et al. (1991) Transplantation of purified islet cells in diabetic rats I. Standardization of islet cell grafts. Diabetes 40: 908-919

12. Pipeleers-Marichal MA, Pipeleers DG, Cutler J, Lacy PE, Kipnis DM (1976) Metabolic and morphologic studies in intraportalislet-transplanted rats. Diabetes 25: 1041-1051

13. Baker J, Metcalf P, Scragg R, Johnson R (1991) Fructosamine Test-Plus, a modified fructosamine assay evaluated. Clin Chem 37: $552-556$

14. Bartels H, Bohmer M (1971) Eine Micromethode zur Kreatininbestimmung. Clin Chim Acta 32: 81-85

15. Wahlefeld AW (1974) Triglycerides. Determination after enzymatic hydrolysis. In: Bergmeyer HU (ed) Methods of enzymatic analysis. Verlag Chemie, Weinheim and Academic Press, New York, London pp 1831-1839

16. Siedel J, Hagele EO, Ziegenhorn J, Wahlefeld AW (1983) Reagent for the enzymatic determination of serum total cholesterol with improved lipolytic efficiency. Clin Chem 29: 1075-1080
17. Pipeleers DG, Pipeleers-Marichal M, Vanbrabandt B, Duys S (1991) Transplantation of purified islet cells in diabetic rats II. Immunogenicity of allografted islet $\beta$-cells. Diabetes 40: 920-930

18. Pipeleers DG, In't Veld PA, Van De Winkel M, Maes E, Schuit FC, Gepts W (1985) A new in vitro model for the study of pancreatic A and B cells. Endocrinology 117: 806-816

19. Pipeleers D (1987) The biosociology of pancreatic B cells. Diabetologia 30: 277-291

20. Orci L (1982) Macro- and micro-domains in the endocrine pancreas. Diabetes 31: 538-565

21. Bonner-Weir S, Orci L (1982) New perspectives on the microvasculature of the islets of Langerhans in the rat. Diabetes 31: 883889

22. Vialettes B, Sutherland DER, Matas AJ, Payne WD, Najarian JS (1979) Amelioration of streptozotocin-induced diabetes in rats: effect of islet isografts on plasma lipids and other metabolic abnormalities. Metabolism 28: 489-494

23. Hesse U, Sutherland DER, Florack G, Field J, Ward S, Najarian JS (1986) Comparison of two methods of islet preparation and transplantation in dogs. Diabetes 35: 1109-1118

Received: 30 January 1992

and in revised form: 13 April 1992

Prof. D. G. Pipeleers

Department of Metabolism and Endocrinology

Vrije Universiteit Brussel

Laarbeeklaan 103

B-1090 Brussels

Belgium 